\title{
Research on Talent Training Mode of School Enterprise Cooperation in Application Oriented Independent College-Case Study on Major of
}

\section{E-commerce}

\author{
Jing $\mathrm{Li}^{1}, \mathrm{Yu} \mathrm{He}^{2 *}$, Yili Zheng \\ ${ }^{1}$ School of Management, Xinhua College of Sun Yat-sen University, China \\ ${ }^{2}$ School of foreign languages, Xinhua College of Sun Yat-sen University, China \\ ${ }^{3}$ School of Management, Xinhua College of Sun Yat-sen University, China \\ E-mail: littlebench117@163.com
}

\begin{abstract}
As a comprehensive interdisciplinary subject, Major of E-Commerce rolls management, economics, and computer technology into one. Practicality, applicability and the fast knowledge updating must be emphasized in the process of cultivating application-oriented E-commerce talents. Schoolenterprise cooperation might be the best way to meet such requirements, especially for the Major's curriculum reform. This paper, beginning with the importance of personnel cultivation based on school-enterprise cooperation, is to analyze the problems current school-enterprise cooperation is faced with, and finally puts forward that school, enterprise and local government should work together in order to cultivate more $\mathbf{E}$ commerce talents.
\end{abstract}

Keywords-School-enterprise Cooperation; Personnel Cultivation Mode; Major of E-commerce; Application-oriented Undergraduate Independent Sub-colleges Colleges

\section{INTRODUCTION}

In early 2014, the Ministry of Education proposed "exploring the vocational education at undergraduate level "in 2014 Key Points of Work; later, with Five Other Authorities, it issued a joint-statement on the Planning for Modern Vocational Education System Construction (2014-2020). In the same year, the State Council issued Accelerating the Development of Modern Vocational Education. All of these manifest the Ministry of education's determination to guide and motivate the local undergraduate colleges and universities to transform into the application-oriented ones [1]. Since that, what should Independent Sub-colleges do to develop its superiority on the course to be an application-oriented one? How to break through the traditional subject-oriented training paradigm based on knowledge system after transformation? Exploring a new personal cultivation mode is critical to solve the problems mentioned above.

As a comprehensive interdisciplinary subject, Major of ECommerce rolls management, economics, and computer technology into one which emphasizes practicality and applicability. To cultivate application-oriented personnel, it's necessary to change traditional passive learning style through a multilevel and multidimensional cooperation between school and enterprise to strengthen practical teaching, focusing on improving students' capability of analysis, organization, knowledge processing and innovation. Construction of personnel cultivation mode based on school-enterprise cooperation can effectively promote school-enterprise collaboration, industry-education integration, work-integrated learning, which is of great practical significance in innovating Application-oriented personnel cultivation mode, cultivating talents of technical application and serving local economy.

\section{THE NEED OF SCHOOL-ENTERPRISE COOPERATION IN LOCAL APPLICATION-ORIENTED UNDERGRADUATE INDEPENDENT SUB-COLLEGES}

\section{A. From the perspective of National-level -- China strongly} advocating school-enterprise Cooperation in higher education

China has spared no effort in promoting deep-level cooperation between vocational education and enterprises in the ways of internship and order-training mode. To guarantee such a cooperation, government has issued a series of provisions and documents at the macro level.

In 2014, the State Council issued Accelerating the Development of Modern Vocational Education, suggesting that local undergraduate colleges and universities should transform into the Application-oriented ones. In 2015, Ministry of Education with two other Authorities issued the instructional advice, calling for the transformation of local undergraduate colleges and universities [2]. These documents make it clear that general colleges, especially local undergraduate colleges and universities, shall mainly aim at cultivating talents with application-oriented technical skills, and comprehensively improving the capacity of severing local economy. Such a transformation inevitably requires the adjustment of schoolrunning orientation and model. School-enterprise cooperation education may offer precious experience in such a transformation, based on which local undergraduate 
independent sub-colleges and universities could cultivate application-oriented talents [3].

In 2015, the Ministry of Education declared Opinions of Deepening the Teaching Reform of Vocational Education and Improving the Quality of Talents Cultivation, pointing out that "Persist in industry-education integration and school-enterprise cooperation; promote connections between educational reform and industrial restructuring and upgrading; strengthen guidance, assessment and service provided by industry; bring enterprises into full play with more participation into the talents cultivation."

B. From the perspective of Schools and Enterprises-- the sound cooperation being beneficial to achieve complementary advantages and improve quality of talents

1) Optimizing teaching resources and complementing each others strengths

School-enterprise cooperation is a new educational mode between College and enterprise in terms of teaching, scientific research and production, which has changed the traditional way of running school on its own power, and has involved the resources possessed by enterprises into colleges' teaching, scientific research in order to optimize educational resources, especially to local colleges and universities. By cooperation with schools, enterprises can get qualified human resources and technical support.

School-enterprise cooperation is ideal for local independent sub-colleges, under which colleges can cultivate application-oriented talents to satisfy the market needs and changes without massive investment, no matter on softwares and hardwares, on curriculum upgrading or faculty recruitment. Enterprises could be the places for teachers and students to apply theory into practice beyond the simulation softwares, which is beneficial to the order-training mode, skills training and cultivation of "double-qualification" teachers.

2) Improving quality of talents, better connecting with Enterprise

Local application-oriented colleges mostly have the inherent disadvantages such as newly-built schools, shortage of teaching staff, poor hard-wares, weak social influence, and so on. Therefore, through school-enterprise cooperation, enterprises can provide teachers with rich practical experience to colleges and universities, and offer places and equipment for daily training and internship. School and enterprises can design personnel training programme together, further to offer vocations for graduates. In turns, schools can make full use of enterprises' resources and places to strengthen students' skills in order to cultivate more high-skilled talents to fit the needs of enterprises.

This will not only promote the cultivation of applicationoriented talents in independent sub-colleges but also meet the needs of enterprises, ensuring zero distance and seamless connection between graduation and employment; meanwhile, it could ease the shortage of softwares and hardwares of colleges, improve the quality of personnel cultivation, and enhance the reputation.

\section{3) Better serving local economy}

"Local" in local univeristies means that universities should cultivate talents to serve the local economy. By developing school-enterprise cooperation, personnel training can be changed from the traditional and blind "output" teaching method into College-enterprise Joint Cultivation Mode. In other words, the colleges should work together with the local companies to share the educational resources and teaching platforms with each other, and directly transit qualified talents into enterprises. Such a mode, combining the enterprises' personnel demand and cultivation of professional talents, has achieved a deep integration between schools and enterprises and improved the locality and practicability of training. Lastly, it meets the needs of enterprises in a more efficient way [4].

\section{THE CURRENT PROBLEMS OF SCHOOL-ENTERPRISE COOPERATION IN LOCAL APPLICATION-ORIENTED INDEPENDENT COLLEGES}

School-enterprise cooperation refers to the cooperation between the higher education institutions and the enterprises, which is not only a double wins mode focusing on the quality of cultivation, school study and business internship practice, and the sharing of the resources and information, but also a better attempt to make the transition in training applicationtype talents of local undergraduate independent colleges. However, in reality there are often some situations like the unilateral good intention of one party, insufficient understanding of the significance, too much emphasize on the short-term return and the cooperation lacking coordination, which lead to a lot of problems to the implementation and management.

\section{A. Both parties lacking the understanding about school- enterprise cooperation}

On the one hand, many undergraduate institutions of higher learning didn't think from the students ' fundamental standpoint while personnel training by school-enterprise cooperation, but to expand the employment channels, they just develop more curriculum and practice chance in enterprise base for senior sophomore, which fundamentally ignored the improvement of personnel training and management quality and students ' individual development.

On the other hand, the enterprises, as the subject of market economy, are endowed with profit-orientated nature. With such a nature, the enterprises is more utilitarian in the cooperation between schools and enterprises, causing an embarrassing situation---"an enthusiastic school and indifferent corporate". At present many enterprises lack basic understanding of school-enterprise cooperation, and only focus on the economic benefits of the current businesses. Regardless of whether the student's specialty matches the job, they first implement replacement teaching practice in order to solve the problem of talents shortage. And that is not fundamentally involved in the whole process of personnel training, which has become a barrier to improve the effectiveness of school-enterprise cooperation.

\section{B. Lack of management system and standards}

School-enterprise cooperation means not simply internship, on the contrary, it should be integrated into the basic goals of 
application-oriented personnel training. The goal shall not only make up for the insufficiency of the theory study in the school but also meet the employment needs of the enterprise in the capabilities systems. In brief, when implementing the schoolenterprise cooperation, we should integrate the theory with the practice and we should focus on the practical value. When it comes to the results, we should be employment-oriented by combining personnel training with employment needs of social enterprise. However, the status quo is that schools are always the initiators and planners of school-enterprise cooperation, while the enterprises only play a passive role and implement selectively. As a result, the practical teaching plan is inconsistent with actual jobs while the training for professional personnel is inconsistent with the employment needs of the enterprise. One of the prominent features of the result lies in that the "practice" divorced from "learning": the schools hope students to learn through internship, but the companies tend to focus on merely "internship" (ie. work and production itself) and ignore the students ' learning. Process of internship becomes "Form over Substance" because there are no constraints of strict training program and no management system. The underlying reasons for it lies in the lack of management system and standards.

In the absence of legal and institutional constraints, the companies' lack incentives of active participation. Hence, the school-enterprise cooperation are mostly dependent on social connections without a stable platform for cooperation and coordination mechanisms, which always leads up short duration cooperation and instability[5].

\section{The insufficient depth of school-enterprise cooperation affecting achievement of teaching goals}

In many cases of school-enterprise cooperation, the school offers only the employment opportunity while the enterprise merely offers a chance for training. Such cases of cooperation rarely reach the core-aims and hence makes hardly any promotional function in the specialization construction of the schools. As for the enterprises, they lack sufficient attention to the personnel training mode, failing to achieve "Combining learning with working". Thus, the teaching content of practice in the enterprises is out of touch with the goal of internship in school. Most internship content is neither "specialty" nor "reality". During the Internship, the students tend to "see more, hear more, but do less". Even though they have opportunities in operation, the operation are often very simple productive work, lacking the practice like managing front-line positions, planning and problem-solving and so on.

This depth of school-enterprise cooperation, has not only greatly affected the realization of personnel training goal, but also restricts the development of school-enterprise cooperation in most higher education institutions.

\section{MODE CONSTRUCTION OF SCHOOL-ENTERPRISE COOPERATION IN LOCAL UNDERGRADUATE INDEPENDENT COLLEGES}

It is a systematic program to implement the transformational development of the local application-oriented independent colleges. Hence, it is obviously insufficient to achieve the goal with only the power of the college itself. This process requires macro-level guidance from government, and more micro-level implementation and promotion from universities, industries and enterprises.

\section{A. Formulating the talents cultivation objective in terms of development of industry and local industrial demand}

While setting the goals for personnel training, the planner should not ignore the the development of industry and local industry demand. Otherwise, the talents cultivation have neither practicability and the local features. E-commerce has developed very rapidly in recent years in China, which not only creates new consumption demand, but also opens up new employment channels and providing the public with new space for starting a business. On the one hand, the rapid growth of ecommerce companies needs large amounts of electronic business talents, while the traditional enterprises also transform and upgrade themselves by combining with e-commerce implementation which also boosts demand for talents. On the other hand, under the background of "mass entrepreneurship and innovation", starting business in the Internet field has reached a new climaxed, and then new demands have been generated, driving the employment and creating more job opportunities [6].

With the continuous expansion of e-commerce, more enterprises start to develop e-commerce mode, driving the demand for e-commerce talents. In terms of e-commerce major, its undergraduate knowledge has strong link with practice, like website construction, network marketing, store operations and other modules, which require enough theoretical knowledge and also some accumulated practical experience. Meanwhile, development of e-commerce varies greatly in different regions and the level of demand for talents. Therefore, the personnel training objective in the electronic commerce major of the local colleges also needs further integration with the needs of local industrial development. It should have distinct local characteristics under the premise of conforming to uniform standards of application-oriented talents cultivation.

\section{B. Perfection of teaching contents in accordance with professional standards and demand for jobs}

Teaching contents system plays a very important role in achieving the personnel training objectives. The academic sector has reached a consensus that the Application-oriented talents cultivation should be oriented by "cultivating ability", on which, but the "ability" here must correspond with the professional standards and specific job requirements. On the one hand, teaching contents system must be based on organic integration of ability training and professional standards which is standard specification for occupational talents training. One the other hand, the system should both cover professional standards" "ability in common" and strengthen "specific abilities" so as to meet employment needs of cooperative enterprises, making training more conducive to service the regional economy and promote employment.

\section{Cultivating double-qualification teachers}

Application-oriented talents training is inseparably related to teaching staff who focus on application-oriented subjects. Hence, it is necessary to build a compound-type faculty in the school-enterprise cooperation for personnel training. Such a 
faculty should be made up of the "double competency" teachers from both colleges and enterprises. The "double competency" teachers from the enterprises refers to the experts in business management positions or technical positions. Currently, the undergraduate independent college is also building the team of double-quality teachers. However, the double-quality faculty has not been included in the professional title system, and there is no incentive mechanism for it. Therefore, it's high time to reform and perfect the standardization of the professional title evaluation in the application-oriented college. Firstly, the requirements of "Double Competency Teacher" should be incorporated into this evaluation system so as to promote teachers cultivation both on theories and application. Secondly, the system of employment and title evaluation for the "Double Competency Teacher" in the enterprises should be introduced. The system should make it clear on the status and the treatment of the "Double Competency Teacher" By doing so, we would lay the foundations of experts participation under schoolenterprise cooperation mode.

Meanwhile, the companies can also hire the full-time teachers from the cooperative colleges to set up a lecturer group of the enterprise, which can both improve teachers ' professional skill and further enrich the students ' theoretical and practical knowledge. Through joint-efforts in developing characteristic curriculum with both the standards of the college and the closing characteristics of the business, in gathering hands-on experience of enterprises and industrial data and integrating these materials into a more systematic knowledge and theory system, the course will enable students to enjoy more systematic knowledge.

\section{The construction of the multichannel and diversified practice platforms of school-enterprise cooperation}

In the School-enterprise cooperation, the practical teaching platform is an important carrier of teaching content. At present, the practical teaching methods in training talents is various under school-enterprise cooperation. In cooperation with enterprises, the professional vocational institute of technology usually take the traditional training modes like the Alternation of Work and Study, "The Order class", etc which bring all-win results to companies, colleges and students. To a certain extent, such modes have achieved the school-enterprise joint construction, joint management and joint personnel training, but it still subjects to a certain limitation and have little achievement in the deeper cooperation. Different from the vocational colleges, the undergraduate institutions vary in talents training position, thus it requires innovation of the construction of practical teaching platform in school-enterprise cooperation.

1) Incorporate business into colleges on the basis of "the Order class" personnel training

"The Order Class" is a kind of mode of society-oriented opening education mainly aiming at vocational talents training. However, it requires systematic thoughts about curriculum development, teaching organization, learning in enterprises and other areas to guarantee profits for the society, colleges, businesses and the students as well, which promote the cultivation of application-oriented talents in college to meet the employment needs of enterprises, and ensure the smooth connection between graduation and employment. At the same time, through sending teachers' working in enterprises and school-enterprise cooperation and communication, teachers' practice and teaching skills can be improved.

As for cooperative businesses with small working site and relatively simple task such as express company, storage and distribution center, distribution node, it will be a good choice to establish "teaching enterprise" with independent subject qualification in the colleges. The teaching Enterprise would be funded and managed by both the college and the enterprises. Such an entity offers a chance for the teachers and students to combine the theoretical study with the practice by participating in the entity operation and management. By this way, the social resources of enterprise can be fully utilized. At the same time, teaching and practice in a real business environment could improve students ' ability to solve practical problems.

2) Implementing 'dual tutorial system' in schools by inviting teachers from other resources

"Dual-tutorial system" refers to assigning teachers as Internal tutor once the students enter the college while appointing another teacher from outside in their third year of college. The internal tutors in school are mainly professional full-time teachers. They have the responsibilities to focus on cultivating students ' learning ability, enhancing students' development space and developing students' learning style by exerting a subtle influence through the teachers ' morality and teaching style. With these efforts, the internal tutors would guide them to master the learning methods for good grades so as to cultivate students ' professional abilities. Meanwhile, the external mentors, coming from senior management positions in enterprises, are mainly on the duty of guiding students to improve their real operation ability, cultivating professional ethics of students and instructing students to experience and generate preliminary professional abilities of judgement and management, solving inefficiency of students ' theoretical learning, and increasing students' practical cognitive ability and ability to adapt to future work.

The last segment of practical teaching lies in the graduation thesis (or graduation design) which is of importance to integrate comprehensive abilities and expertise of the graduates. It is also the core of practical teaching. Therefore, it is of great significance for both the school and enterprise to jointly instruct graduation thesis. That's to say the part-time tutors and the full-time tutors need to participate in students' selection on topic of thesis and the writing process. First of all, the topic of graduation thesis (design) should be selected from enterprises' productive management practice within real problems and real data. Secondly, enterprise mentors should be professional and technical personnel or managers from departments related to the topic of thesis. The guiding of the Paper is to lead the student teams to solve practical problems. Finally, school and business mentors and students explore the solution of problem and implement and verify it together.

\section{E. The formation of management system and standardization in school-enterprise cooperation}

In China nowadays, although the central and local government have issued a series of political documents, encouraging school-enterprise cooperation, the alternation of 
work-study and integration of production. However, these files mostly remain at the macro-level without forming specific guidance, resulting in more programmatic property than practical meaning. Therefore, school-enterprise cooperation is a systematic project. If there are no special laws defining the rights and obligations of schools and enterprises, no third-party supervision organization, no security policies on finances, taxation, education, personnel and other relevant areas, the cooperation will have be inevitably restricted in the shallow level and faced with unsuitability.

\section{CONCLUSION}

As a comprehensive multidiscipline subject, traditional way of the talents' cultivation characterized by passive learning fails to meet the fast development of E-commerce. Instead, the practice teaching mode based on multi-level and multi dimension school-enterprise's cooperation follows the tide, enhancing students' capability of analysis, organization, knowledge process and innovation. Through formulating the talents cultivation objective in terms of development of industry and local industrial demand, perfecting of teaching contents in accordance with professional standards and demand for jobs, cultivating double-qualification teachers, constructing the multichannel and diversified practice platforms of school-enterprise cooperation, the local Application-oriented Undergraduate Independent Sub-colleges can cultivate more talents to server local economy.

In short, as for local independent schools, we have a clear direction of the application-oriented transformation. Application-oriented colleges should take measures step by step on the road to transformation, through the construction of personnel training mode based on school-enterprise cooperation. This will effectively promote school-enterprise cooperation and joint cooperation with teaching, which plays a very important role in training applied innovative talents and serving regional economy.

\section{ACKNOWLEDGMENT}

Fund Programs: 2015 Guangdong Province Key Platform and Scientific Research Project (2015GXJK194), Guangdong Province Quality Project E-commerce Foundation Excellent Course (2016JP008)

About the Authors:

Li Jing (1983- ), female, master's degree, lecturer of Xinhua College of Sun Yat-sen University, researching in Ecommerce and network marketing.

$\mathrm{He} \mathrm{Yu} \mathrm{(1982-} \mathrm{),} \mathrm{female,} \mathrm{master's} \mathrm{degree,} \mathrm{lecturer} \mathrm{of} \mathrm{Xinhua}$ College of Sun Yat-sen University, researching in business English and cross-border E-commerce.

Zheng YiLi (1995- ), female, undergraduate student, Xinhua College of Sun Yat-sen University.

\section{REFERENCES}

[1] General Office of the State Council, Li Keqiang, presided over the executive meeting of the State Council, [EB/OL]. http://www.gov.cn/ldhd/2014-02/26/content_2622673.htm

[2] Guidance on guiding some local universities to the application transformation ([2015]7) [Z].2015-10-21.

[3] Provincial Education Department, the provincial development and Reform Commission, the Provincial Department of Finance on the guidance of some ordinary undergraduate colleges and universities to implement the transformation of the implementation of the views (Guangdong Jiao Gao [2016]5, [Z].2016-6-16.

[4] ZhiPing Wan, Shuang Liu, Jing Li, Feng Wang, Research on the Strategic Development of the Reform and Transformation of Independent College to Application-Oriented College-Deepen the reform of the system and mechanism of application-oriented college, Advances in Social Science, Education and Humanities Research (Volume 75), 2016.

[5] Zheng Liu, Exploration of talent training mode of school enterprise cooperation in Local Applied Universities -- Taking logistics management major as an example"(In Chinese)", Higher Education Exploration(No.3), 2017.

[6] XiaoYan Wang, The mode and experience of higher education reform in foreign university enterprise cooperation "(In Chinese)", Heilongjiang Researches on Higher Education(No.6), 2016. 